\title{
Plankton Resting Stages in the Marine Sediments of the Bay of Vlorë (Albania)
}

\author{
Fernando Rubino, ${ }^{1}$ Salvatore Moscatello, ${ }^{2}$ Manuela Belmonte, ${ }^{1,2}$ \\ Gianmarco Ingrosso, ${ }^{2}$ and Genuario Belmonte ${ }^{2}$ \\ ${ }^{1}$ Laboratory of Plankton Ecology, IAMC CNR, UOS Talassografico "A. Cerruti," 74123 Taranto, Italy \\ ${ }^{2}$ Laboratory of Zoogeography and Fauna, CoNISMa U.O. Lecce, DiSTeBA University of the Salento, 73100 Lecce, Italy
}

Correspondence should be addressed to Genuario Belmonte; genuario.belmonte@unisalento.it

Received 13 December 2012; Accepted 1 April 2013

Academic Editor: Sami Souissi

Copyright ( 2013 Fernando Rubino et al. This is an open access article distributed under the Creative Commons Attribution License, which permits unrestricted use, distribution, and reproduction in any medium, provided the original work is properly cited.

\begin{abstract}
In the frame of the INTERREG III CISM project, sediment cores were collected at 2 stations in the Gulf of Vlore to study the plankton resting stage assemblages. A total of 87 morphotypes were identified and produced by Dinophyta, Ciliophora, Rotifera, and Crustacea. In 22 cases, the cyst belonged to a species absent from the plankton of the same period. The most abundant resting stages were those produced by Scrippsiella species (Dinophyta). Some calcareous cysts were identified as fossil species associated with Pleistocene to Pliocene sediment, although they were also found in surface sediments and some of them successfully germinated, thus proving their modern status. Total abundance generally decreased with sediment depth at station 40, while station 45 showed distinct maxima at 3 and $8 \mathrm{~cm}$ below the sediment surface. The depth of peak abundance in the sediment varied with species. This paper presents the first study of the plankton resting stages in the Bay of Vlorë. The study confirmed the utility of this type of investigation for a more correct evaluation of species diversity. In addition, the varying distribution with sediment depth suggests that this field could be of some importance in determining the history of species assemblages.
\end{abstract}

\section{Introduction}

Resting stages produced by plankton organisms in temperate seas accumulate in the bottom sediments of confined coastal areas [1]. Their assemblages represent reservoirs of biodiversity which sustain the high resilience of plankton communities, providing recruits of propagules at each return of favourable conditions, in accordance with the so-called Supply Vertical Ecology model [2]. The existence of benthic stages in the life cycles of holoplankton provides a new key for understanding the role of life cycles in the pelagic-benthic relationship in coastal waters $[3,4]$. Consequently, assessments of biodiversity at marine sites should take account of the unexpressed fraction of the plankton community contained in the bottom sediments by performing integrated sampling programs $[5,6]$. Despite the proven importance of resting stage banks in coastal marine ecology, the issue of "resting versus active" plankters has commonly been considered for single taxa and only rarely from the wholecommunity point of view. This is probably due to the great complexity (compositional, functional, and distributional) of resting stage banks. Indeed, it has been demonstrated that at any given moment the species assemblages in bottom sediments (as resting stages) are quite different from the species detectable in the water column (as active stages) $[6,7]$. However, the study of such marine "seed banks" (as understood by [3], analogous to terrestrial seed banks in forest soils) is complex on many levels. Resting stages share a common morphological plan despite belonging to organisms from different kingdoms [8]. Consequently, resting stage morphology differs sharply from that of active stages and in some cases their identification is highly problematic. However, it is also true that for some naked dinoflagellates or for thecate ones with a similar thecal plate pattern, cysts are quite different, allowing correct identification without the use of SEM or molecular techniques. Cyst-producing 
dinoflagellates differ in the length of their life cycle and/or the timing of cyst production, and the rest capacity of resting stages also varies. They are generally programmed to rest for the duration of the adverse period, but fractions of them can also rest for longer periods, allowing the population to reappear decades later, ([9-11], for copepods, [12, 13], for dinoflagellates). Hairston et al. [14] reported a rest of more than 300 years for a calanoid resting egg, albeit of a freshwater species.

The scarcity of literature on whole resting stage communities encouraged us to describe situations in various parts of the Mediterranean, in order to obtain a rich data set useful for building models and in experimental situations. Here a detailed description of the structure of the marine "seed bank" produced by plankton in the Bay of Vlore is reported.

The present study also focuses on an Albanian bay that has not been extensively studied from the marine biodiversity point of view. The data from the benthos are compared with analyses of the phytoplankton and microzooplankton [15] in the water column to assess with more precision the biodiversity of the plankton in the Bay of Vlorë.

Moscatello et al. [15] reported that the microzooplankton community of the Bay of Vlorë was composed of more than 200 taxa, of which 97 were classified as "seasonally absent." The aim of the present paper is to determine whether these absences in the water column correspond to resting stages in the sediments.

\section{Materials and Methods}

2.1. Study Site. An oceanographic campaign was carried out in the Bay of Vlorë from 17th to 23rd of January 2008 aboard the oceanographic vessel "Universitatis". This survey was conducted as part of the PIC Interreg III Italy, Albania Project for providing technical assistance for the management of an International Centre of Marine Sciences (CISM) in Albania. The sampling period of the present study (January 2008) coincided with that of Moscatello et al. [15] who investigated active plankton in the water column in the same area.

In order to investigate the presence and distribution of resting stages produced by plankton species in the area, 2 stations were chosen, representing 2 different types of environment: a deep zone (station 40, depth: $54 \mathrm{~m}$ ), with sediments of terrigenous mud dominated by Labidoplax digitata (Holothuroidea) and a shallower site (station 45, depth: $28 \mathrm{~m}$ ), with sediments of terrigenous mud dominated by Turritella communis (Gastropoda) (Figure 1) (for the classification of mud biocenosis in the Bay of Vlorë, see [16]).

2.2. Sampling Procedure. Samples of bottom sediments were collected in three replicates (named $40 \mathrm{a}, \mathrm{b}, \mathrm{c}$ and $45 \mathrm{a}, \mathrm{b}, \mathrm{c}$ ) using a Van Veen grab with upper windows that allowed the collection of undisturbed sediment cores. At each station, 2 different PVC corers (h: $30 \mathrm{~cm}$, inner $Q 4$ and $8 \mathrm{~cm}$ ) were used in order to obtain 2 different sets of samples. The smaller core was processed to obtain cysts of protists; the larger core was processed to obtain resting eggs of metazoans. This differentiation was necessary because metazoan resting

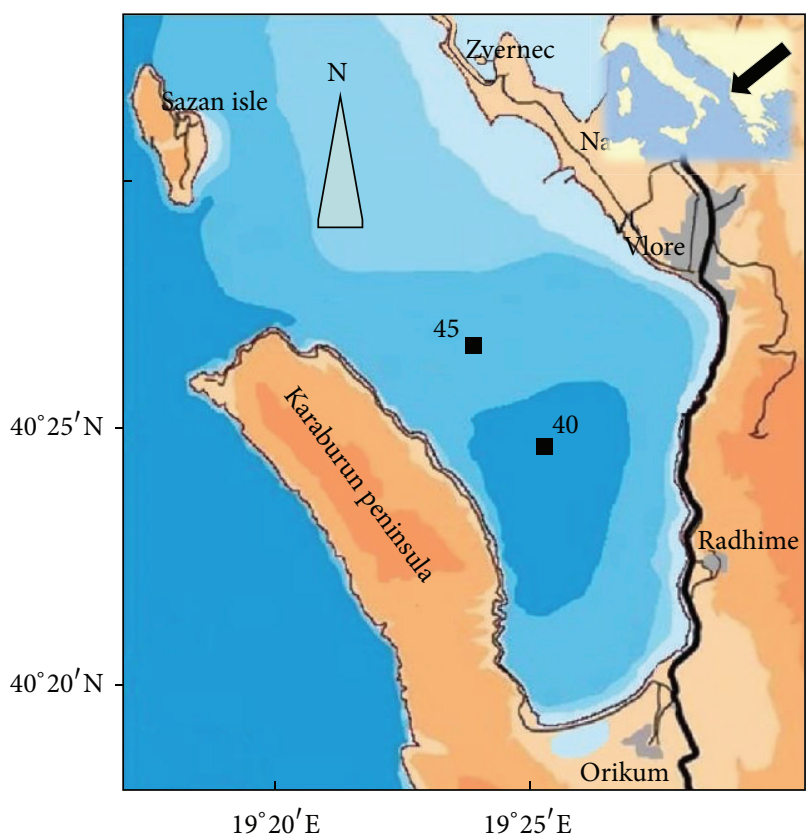

FIGURE 1: Map of study area showing location of two sampling stations $(40,45)$ in Bay of Vlorë (Albania).

stages are less abundant, so a greater amount of sediment is required. Moreover, their walls are only organic, allowing the adoption of a centrifugation method coupled with filtration to obtain a "clean" sample from a relatively large quantity of sediment. In contrast, protistan cysts are more abundant and have different types of walls (calcareous, siliceous, organic), which complicates the procedure when the whole cyst bank is studied. Thus, the most fruitful method of separating cysts from sediment is filtration through meshes of different sizes.

After extraction, sediment cores were immediately subdivided into $1 \mathrm{~cm}$ thick layers, until the 15 th $\mathrm{cm}$ from the sediment surface. The thickness of $15 \mathrm{~cm}$ was chosen because in previous studies we noted that abundances diminished significantly at depths of more than $7-10 \mathrm{~cm}$ below the sediment surface $[1,12]$. The outer edge of each layer was discarded to avoid contamination from material from the overlaying layer during the insertion of the corer into the sediments. Once obtained, the samples were stored in the dark at $5^{\circ} \mathrm{C}$ until treatment in the laboratory.

2.3. Protistan Cysts $(20-125 \mu \mathrm{m})$. In the laboratory the smallcore samples were treated using a sieving technique consisting of the following steps.

(i) The entire sample is homogenized and then subsampled, obtaining $3-5 \mathrm{~mL}$ of wet sediment which is passed through a $20 \mu \mathrm{m}$ mesh (Endecott's LTD steel sieves, ISO3310-1, London, England), using natural filtered $(0.45 \mu \mathrm{m})$ seawater (Gulf of Taranto).

(ii) The retained fraction is ultrasonified for $1 \mathrm{~min}$ and again passed through a series of sieves $(125,75$, and $20 \mu \mathrm{m}$ mesh sizes), obtaining a fine-grained fraction $(20-75 \mu \mathrm{m})$ containing most of the protistan cysts 
and a $75-125 \mu \mathrm{m}$ fraction with the larger ones (e.g., Lingulodinium spp.) and the zooplankton resting eggs. The material retained by the $125 \mu \mathrm{m}$ mesh was not considered.

No chemicals were used to disaggregate sediment particles, in order to avoid the dissolution of calcareous and siliceous cyst walls.

Qualitative and quantitative analyses were carried out under an inverted microscope (Zeiss Axiovert S100 equipped with a Nikon Coolpix 990 digital camera) at 200 and 320 magnifications. Both full (i.e., probably viable) and empty (i.e., probably germinated) cysts were considered. At least $1 / 5$ of the finer fraction and all of the $>75 \mu \mathrm{m}$ fraction were analyzed.

All the resting stage morphotypes were identified on the basis of published descriptions, ([17-19], for dinoflagellates, $[20,21]$, for ciliates and germination experiments).

Identification was performed to the lowest possible taxonomic level. As a rule, modern, biological names were used. The paleontological name is reported only for morphotypes whose active stage was not known.

A fixed aliquot $(\approx 5 \mathrm{~g})$ of wet sediment from each sample was oven-dried at $70^{\circ} \mathrm{C}$ for $24 \mathrm{~h}$ to calculate the water content and obtain quantitative data for each taxon as cysts $\mathrm{g}^{-1}$ of dry sediment.

2.4. Metazoan Resting Eggs $(45-200 \mu \mathrm{m})$. For the analysis of the large-core samples the Onbè [22] method was used, slightly modified by using 45 and $200 \mu \mathrm{m}$ mesh sizes to obtain a size range typical of mesozooplankton resting eggs.

For each sample a fixed quantity of wet sediment was treated $\left(\approx 45 \mathrm{~cm}^{3}\right)$.

Only full (i.e., probably viable) resting eggs were counted and quantitative data for each taxon are reported as resting eggs $\times 100 \mathrm{~g}^{-1}$ of dry sediment.

2.5. Germination Experiments. To achieve germination, all putative viable cysts of protists isolated from the sediment were individually positioned in Nunclon microwells (Nalge Nunc International, Roskilde, Denmark) containing $\approx 1 \mathrm{~mL}$ of natural sterilized seawater. Cysts were incubated at $20^{\circ} \mathrm{C}$, $12: 12 \mathrm{~h}$ LD cycle, $100 \mu \mathrm{E} \mathrm{m}^{-2} \mathrm{sec}^{-1}$ irradiance, and examined on a daily basis, until germination up to a maximum of 30 days. The incubation conditions were chosen on the basis of previous studies $[5,6,23]$. They have proved to be effective for a large number of species.

2.6. Data Analysis. For the 1st $\mathrm{cm}$ of the cores, data on resting stage abundance from the 2 sampling stations were obtained by merging the data from the 3 replicates of the 2 sets of samples (those for protistan cysts and metazoan resting eggs). For samples below the first $\mathrm{cm}$, only the $45-200 \mu \mathrm{m}$ fraction was used, in order to facilitate and accelerate the analysis. From the abundance matrices (taxa versus stations and taxa versus station and $\mathrm{cm}$ respectively) of both surface and deeper sediments, the Bray Curtis similarity measure was calculated after 4 th root transformation in order to allow rare species to become more evident.

The PRIMER “DIVERSE” function (Primer-E Ltd, Plymouth, UK) was used to calculate the taxonomic richness $(S)$, taxon abundance $(N)$, Margalef index $(d)$, Shannon-Wiener diversity index $\left(H^{\prime}\right)$, and Pielou's evenness index $\left(J^{\prime}\right)$ for each sample.

The relationships between the samples collected at the 2 stations were analyzed by means of nonmetric multidimensional scaling (nMDS) with superimposed hierarchical clustering with a cutoff at $60 \%$ similarity (for surface sediments) and 70\% (for the sediment core as a whole), while the SIMPER routine was used to identify relative dissimilarity and the taxa that contributed most to the differences.

The statistical significance of the differences between the 2 stations was calculated by means of a 2-way crossed analysis of similarities (ANOSIM) on the Bray-Curtis similarity matrix based on the stratigraphy.

All univariate and multivariate analyses were performed using PRIMER v.6 (Primer-E Ltd, Plymouth, UK).

\section{Results}

3.1. Total Biodiversity. Resting stages were found at all levels of the $15 \mathrm{~cm}$ sediment core columns from the 2 investigated sites in the Gulf of Vlorë.

Merging the data from the 2 sets of samples $(20-125 \mu \mathrm{m}$ and $45-200 \mu \mathrm{m}$ ) and considering both full (probably viable) and empty (probably germinated) forms from each station, 87 different resting stage morphotypes produced by plankton were recognized (Table 1). Most of them (59, belonging to 20 genera) were dinoflagellates, 16 were ciliates (9 genera), 4 rotifers ( 2 genera), and 5 crustaceans (4 genera), while 3 (1 protistan cyst type and 2 resting eggs) remained unidentified. Station 40 showed higher biodiversity, with 79 morphotypes, 35 of them exclusive to the site. At station 45, 52 morphotypes were observed, 8 of them being exclusive.

Moreover, analysis of the empty forms found among the $20-125 \mu \mathrm{m}$ fraction led to the recognition of 11 morphotypes, all dinoflagellates.

A total of 36 cyst types were identified as taxa missing from the plankton list of the same period (January 2008; [15]). Partly due to nomenclature problems, uncertainty of identification, and differences in examined periods, it was possible to ascertain the contemporaneous presence of species in both pelagic and benthic compartments only in a very few cases.

Identification was frequently impossible due to the presence of previously unreported resting stage morphologies. In such cases, germination experiments allowed the cysts to be attributed to a high level taxon at least, as with a Strombidium (Ciliophora) cyst, whose morphology is reported here for the first time (see Figure 2).

3.2. Surface Sediments. The analysis of surface sediments (the 1 st $\mathrm{cm}$ of the cores), that is, those most affected by cyst deposition and resuspension/germination, revealed sharp differences between the 2 analysed stations. In total, 36 
TABLE 1: List of resting stage (cyst) morphotypes recovered from sediments of Bay of Vlorë (Albania).

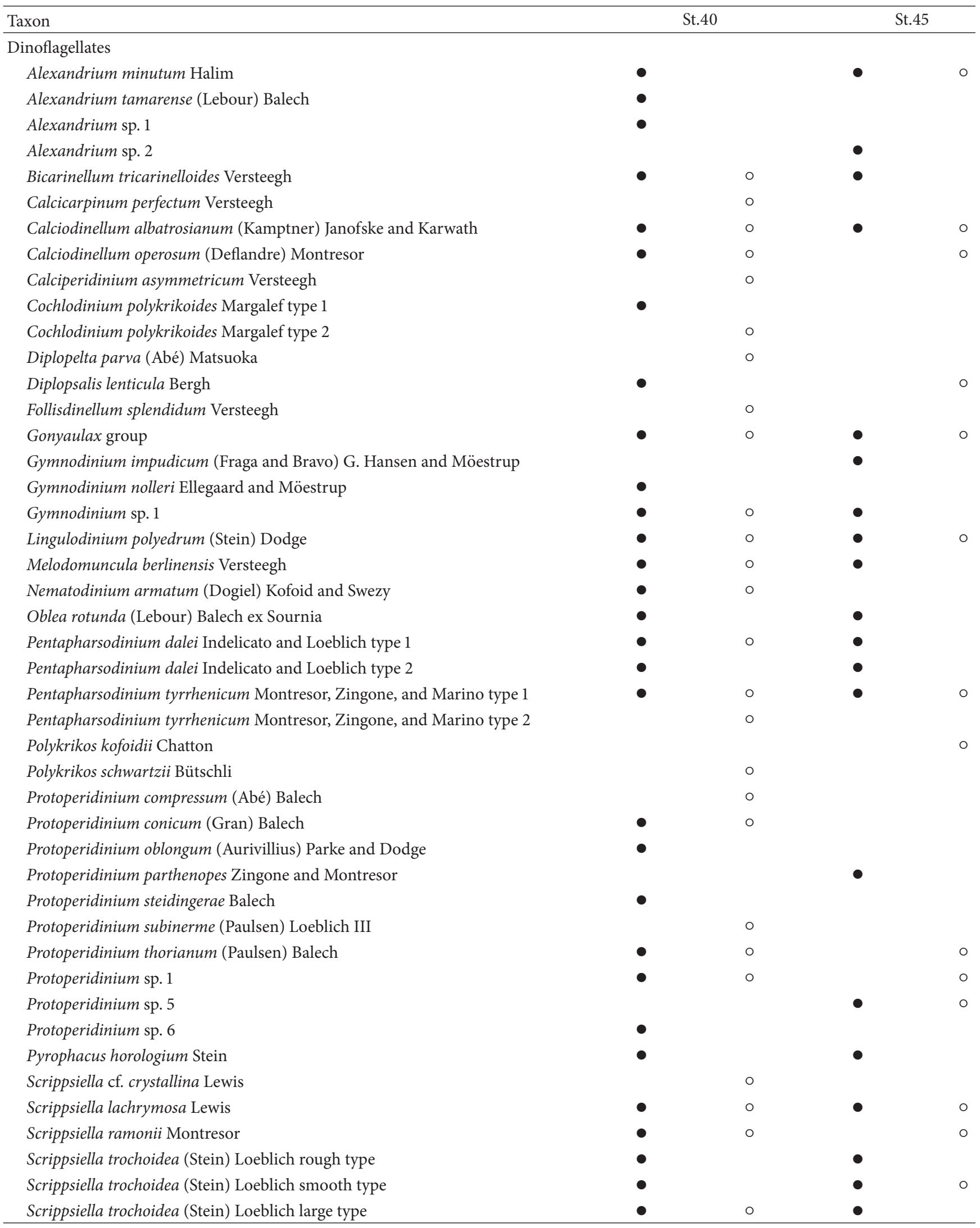


TABle 1: Continued.

\begin{tabular}{|c|c|c|c|c|}
\hline Taxon & & & & \\
\hline Scrippsiella trochoidea (Stein) Loeblich medium type & $\bullet$ & ० & $\bullet$ & o \\
\hline Scrippsiella trochoidea (Stein) Loeblich small type & $\bullet$ & $\circ$ & $\bullet$ & \\
\hline Scrippsiella sp. 1 & $\bullet$ & $\circ$ & $\bullet$ & ० \\
\hline Scrippsiella sp. 4 & $\bullet$ & & $\bullet$ & \\
\hline Scrippsiella sp. 5 & $\bullet$ & & $\bullet$ & \\
\hline Scrippsiella sp. 6 & $\bullet$ & & $\bullet$ & \\
\hline Scrippsiella sp. 8 & • & ○ & $\bullet$ & \\
\hline Thoracosphaera sp. & $\bullet$ & & $\bullet$ & \\
\hline Dinophyta sp. 2 & $\bullet$ & & $\bullet$ & \\
\hline Dinophyta sp. 7 & $\bullet$ & & $\bullet$ & \\
\hline Dinophyta sp. 17 & • & & & \\
\hline Dinophyta sp. 26 & $\bullet$ & & & \\
\hline Dinophyta sp. 30 & $\bullet$ & & & \\
\hline Dinophyta sp. 33 & $\bullet$ & & $\bullet$ & \\
\hline Ciliates & & & & \\
\hline Codonella aspera Kofoid and Campbell & $\bullet$ & & & \\
\hline Codonella orthoceras Heackel & $\bullet$ & & & \\
\hline Codonellopsis monacensis (Rampi) Balech & $\bullet$ & & & \\
\hline Codonellopsis schabii (Brandt) Kofoid and Campbell & $\bullet$ & & $\bullet$ & \\
\hline Epiplocylis undella (Ostenfeld and Schmidt) Jörgensen & $\bullet$ & & $\bullet$ & \\
\hline Rabdonella spiralis (Fol) Brandt & $\bullet$ & & & \\
\hline Stenosemella ventricosa (Claparède and Lachmann) Jörgensen & $\bullet$ & & $\bullet$ & \\
\hline Strobilidium sp. & $\bullet$ & & $\bullet$ & \\
\hline Strombidium cf. acutum (Leegaard) Kahl & $\bullet$ & & $\bullet$ & \\
\hline Strombidium conicum (Lohman) Wulff & & $\circ$ & $\bullet$ & \\
\hline Tintinnopsis beroidea Stein & $\bullet$ & & & \\
\hline Tintinnopsis butschlii Kofoid and Campbell & $\bullet$ & & & \\
\hline Tintinnopsis campanula Ehrenberg & $\bullet$ & & & \\
\hline Tintinnopsis cylindrica Daday & - & & $\bullet$ & \\
\hline Tintinnopsis radix (Imhof) & & & $\bullet$ & \\
\hline Undella claparedei (Entz) Daday & $\bullet$ & & & \\
\hline Rotifers & & & & \\
\hline Brachionus plicatilis Müller & $\bullet$ & & & \\
\hline Synchaeta sp. spiny type & $\bullet$ & & & ० \\
\hline Synchaeta sp. rough type & $\bullet$ & & & \\
\hline Synchaeta sp. mucous type & $\bullet$ & & & \\
\hline Crustaceans Cladocerans & & & & \\
\hline Penilia avirostris Dana & $\bullet$ & & • & \\
\hline Crustaceans Copepods & & & & \\
\hline Acartia clausi/margalefi & $\bullet$ & & & \\
\hline Acartia sp. 1 & $\bullet$ & $\circ$ & $\bullet$ & ० \\
\hline Centropages sp. & $\bullet$ & & $\bullet$ & ० \\
\hline Paracartia latisetosa (Krizcaguin) & $\bullet$ & $\circ$ & $\bullet$ & \\
\hline Unidentified & & & & \\
\hline Cyst type 1 & & & $\bullet$ & \\
\hline Resting Egg 1 & & & $\bullet$ & \\
\hline Resting Egg 9 & $\bullet$ & & & \\
\hline
\end{tabular}

-: cysts observed as full (i.e., probably viable). o: cysts observed as germinated (i.e., empty). 


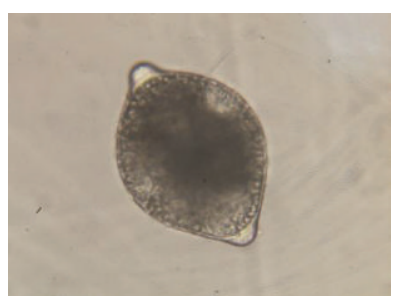

(a)
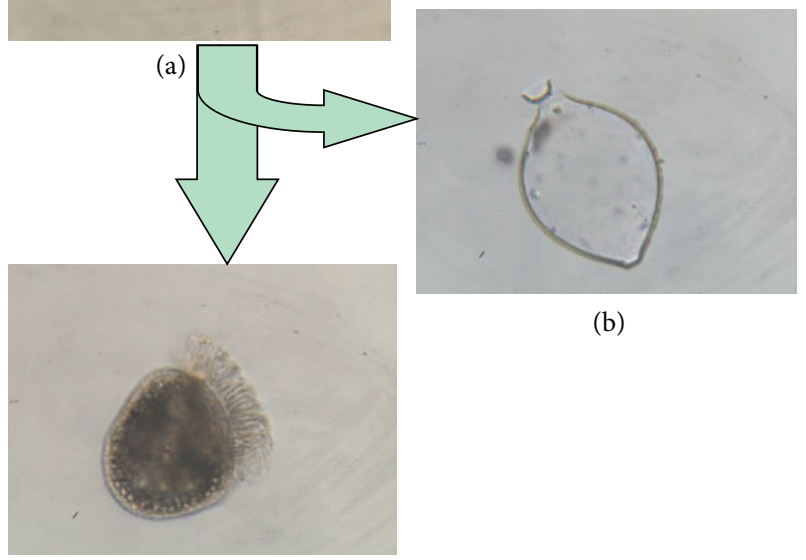

(b)

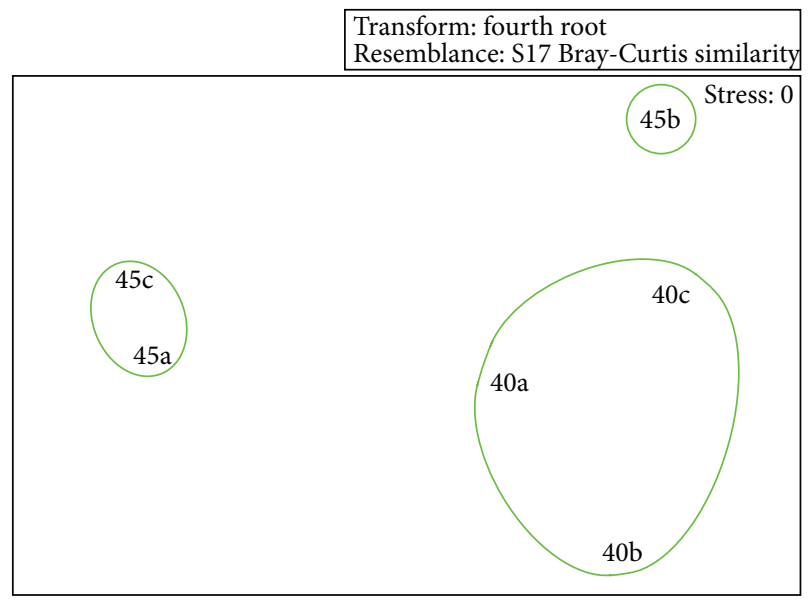

FIGURE 3: nMDS plot of surface sediment samples collected at stations 40 and 45 in Bay of Vlorë. Hierarchical clustering superimposed with cutoff at $60 \%$ similarity.

(c)

FIgURE 2: Photographs of Ciliophora cyst, with two opposite papulae (a). Its empty shell (hatch occurs from one of two papulae) (b). Germinated active stage, Strombidium ciliate (c).

different resting stage morphotypes were observed in this first layer (Table 2), 23 produced by dinoflagellates, 6 by ciliates, 2 by rotifers, 4 by crustaceans, and 1 undetermined. Even considering the small amount of available data, station 40 showed higher biodiversity, in terms of both number of taxa and diversity indexes (see Table 3). Total abundances were comparable, however, with $389 \pm 127$ cysts g $^{-1}$ (average \pm s.d.) at station 40 versus $329 \pm 123$ cysts g $^{-1}$ at station 45 . SIMPER showed 58\% dissimilarity between the assemblages of the two sites (Table 4).

The most abundant cyst morphotypes in the surface layers were calcareous cysts produced by species of the Calciodinellaceae family (Dinophyta). At station 40, five cyst morphotypes of this family accounted for $95 \%$ of total abundance, while at station $45,99 \%$ was accounted for by just one cyst morphotype, Scrippsiella trochoidea medium type, confirming the lower evenness at this station.

The nMDS ordination (Figure 3, stress $=0$ ), with the hierarchical cluster superimposed with a cutoff at $60 \%$ similarity, clearly reflects the separation between the samples from stations 40 and 45 . Among these, due to its higher diversity, sample $45 \mathrm{~b}$ is farther from samples $45 \mathrm{a}$ and $45 \mathrm{c}$ than it is from the samples of station 40 .

3.3. Whole Sediment Cores. At both the investigated stations, a general decrease in total abundances was observed with depth along the sediment columns. At station 40, higher total abundance and diversity values than station 45 were registered (Figure 4), with a sharp decline between the 6th and 7th centimetres. Beyond this depth, total abundance remained below 100 cysts $100 \mathrm{~g}^{-1}$. In terms of species, Codonellopsis

schabii cysts and Synchaeta sp. and Acartia clausi/margalefi resting eggs were continuously observed along the whole sediment column at both stations. The ciliate C. schabii was by far the most abundant taxon at station 40 (43\% of total abundance), with density highest in the 2nd cm (342 \pm 192 cysts $100 \mathrm{~g}^{-1}$ ); as with total abundance, a sharp decrease was observed between the 6th and 7th centimetres. Other important species were the copepods Centropages sp. (181 \pm 50 resting eggs $100 \mathrm{~g}^{-1}$ at 4 th $\left.\mathrm{cm}\right)$ and Acartia spp. (67 \pm 32 resting eggs $100 \mathrm{~g}^{-1}$ at 1 st $\mathrm{cm}$ ). At station 45 the most abundant type was Acartia spp. ( $86 \pm 57$ resting eggs $100 \mathrm{~g}^{-1}$ at 1st $\mathrm{cm})$ followed by C. schabii $\left(70 \pm 60\right.$ cysts $100 \mathrm{~g}^{-1}$ at 4 th $\mathrm{cm})$ and Synchaeta sp. (41 \pm 23 resting eggs $100 \mathrm{~g}^{-1}$ at 5 th $\mathrm{cm}$ ).

In the nMDS ordination (Figure 5, stress $=0.12$ ) with superimposition of the hierarchical cluster with a cutoff at $70 \%$ similarity, all the samples from station 45 cluster together, while the samples from station 40 were widely dispersed, a sign of greater variability at this site.

The assemblage structure of the two stations differed significantly at all layers (ANOSIM $R=0.655 ; P=0.001$ ), showing 59\% dissimilarity (SIMPER, Table 5).

3.4. Germination Experiments. All putatively viable (i.e., full) protistan cyst types observed were isolated and incubated under controlled conditions to obtain germination. Successful germination generally allowed us to confirm the cyst-based identification, but in some cases it enabled us to go beyond this and discriminate between cysts sharing similar morphology. For example, Alexandrium minutum and Scrippsiella sp. 1, both have a round cyst with a thin and smooth wall with mucous material attached, Protoperidinium thorianum and Protoperidinium sp. 1 cysts are both roundbrown and smooth, and Gymnodinium nolleri and Scrippsiella sp. 4 both produce round-brown cysts with a red spot inside. The germination of all these cyst types allowed us to correctly identify these species. 
TABLE 2: Abundance (cysts $\mathrm{g}^{-1} \mathrm{dw}$ ) of probably viable resting stages (cysts) observed in surface sediments of two stations in Bay of Vlorë (Albania). Values from three replicates are reported.

\begin{tabular}{|c|c|c|c|c|c|c|}
\hline & $40 \mathrm{a}$ & $40 \mathrm{~b}$ & $40 \mathrm{c}$ & $45 a$ & $45 b$ & $45 c$ \\
\hline Calciodinellum albatrosianum & 20.1 & 18.3 & 35.1 & 0.0 & 0.0 & 0.0 \\
\hline Calciodinellum operosum & 0.0 & 0.0 & 11.7 & 0.0 & 0.0 & 0.0 \\
\hline Gonyaulax group & 20.1 & 0.0 & 0.0 & 0.0 & 0.0 & 59.6 \\
\hline Gymnodinium sp. 1 & 20.1 & 9.2 & 0.0 & 0.0 & 22.2 & 0.0 \\
\hline Lingulodinium polyedrum & 40.2 & 0.0 & 0.0 & 0.0 & 0.0 & 0.0 \\
\hline Melodomuncula berlinensis & 40.2 & 0.0 & 0.0 & 0.0 & 0.0 & 0.0 \\
\hline Oblea rotunda & 0.0 & 0.0 & 11.7 & 0.0 & 0.0 & 0.0 \\
\hline Pentapharsodinium dalei type 1 & 20.1 & 0.0 & 0.0 & 0.0 & 11.1 & 0.0 \\
\hline Pentapharsodinium tyrrhenicum type 1 & 40.2 & 18.3 & 23.4 & 0.0 & 11.1 & 0.0 \\
\hline Protoperidinium sp. 1 & 0.0 & 9.2 & 0.0 & 0.0 & 0.0 & 0.0 \\
\hline Protoperidinium sp. 5 & 0.0 & 0.0 & 11.7 & 0.0 & 11.1 & 0.0 \\
\hline Scrippsiella ramonii & 0.0 & 9.2 & 0.0 & 0.0 & 0.0 & 0.0 \\
\hline Scrippsiella trochoidea rough type & 40.2 & 18.3 & 46.8 & 0.0 & 0.0 & 0.0 \\
\hline Scrippsiella trochoidea smooth type & 0.0 & 9.2 & 11.7 & 0.0 & 11.1 & 0.0 \\
\hline Scrippsiella trochoidea medium type & 181.0 & 73.3 & 105.4 & 173.1 & 111.1 & 238.4 \\
\hline Scrippsiella trochoidea small type & 80.5 & 64.2 & 58.5 & 230.8 & 0.0 & 0.0 \\
\hline Scrippsiella sp. 1 & 20.1 & 0.0 & 11.7 & 0.0 & 11.1 & 0.0 \\
\hline Scrippsiella sp. 4 & 0.0 & 9.2 & 0.0 & 0.0 & 0.0 & 0.0 \\
\hline Thoracosphaera sp. 1 & 0.0 & 0.0 & 11.7 & 0.0 & 11.1 & 0.0 \\
\hline Dinophyta sp. 2 & 0.0 & 0.0 & 23.4 & 0.0 & 0.0 & 0.0 \\
\hline Dinophyta sp. 17 & 0.0 & 18.3 & 0.0 & 0.0 & 0.0 & 0.0 \\
\hline Dinophyta sp. 26 & 0.0 & 18.3 & 0.0 & 0.0 & 0.0 & 0.0 \\
\hline Dinophyta sp. 33 & 0.0 & 0.0 & 0.0 & 0.0 & 11.1 & 0.0 \\
\hline Codonellopsis schabii & 1.0 & 0.0 & 0.9 & 0.6 & 0.3 & 0.5 \\
\hline Stenosemella ventricosa & 0.1 & 0.0 & 0.0 & 0.0 & 0.0 & 0.0 \\
\hline Strobilidium sp. & 0.1 & 0.0 & 0.1 & 0.0 & 0.0 & 0.0 \\
\hline Strombidium acutum & 0.0 & 0.0 & 0.0 & 0.0 & 11.1 & 0.0 \\
\hline Tintinnopsis cylindrica & 0.0 & 0.0 & 0.0 & 0.0 & 0.1 & 0.1 \\
\hline Undella claparedei & 0.1 & 0.0 & 0.1 & 0.0 & 0.0 & 0.0 \\
\hline Brachionus plicatilis & 0.2 & 0.0 & 0.1 & 0.3 & 0.0 & 0.1 \\
\hline Synchaeta sp spiny type & 0.3 & 0.2 & 0.0 & 0.2 & 0.0 & 0.1 \\
\hline Penilia avirostris & 0.0 & 0.0 & 0.1 & 0.0 & 0.0 & 0.0 \\
\hline Acartia clausi/margalefi & 1.0 & 0.3 & 0.7 & 1.5 & 0.3 & 0.8 \\
\hline Acartia sp. 1 & 0.1 & 0.0 & 0.1 & 0.0 & 0.0 & 0.0 \\
\hline Centropages sp. & 0.3 & 0.2 & 0.0 & 0.2 & 0.1 & 0.2 \\
\hline Cyst type 1 & 0.0 & 0.0 & 0.0 & 57.7 & 0.0 & 0.0 \\
\hline
\end{tabular}

TABLE 3: Abundance and diversity indices calculated for resting stages in surface sediments at two stations investigated in Bay of Vlorë.

\begin{tabular}{|c|c|c|c|c|c|c|}
\hline & $\begin{array}{l}\text { Abundance } \\
\text { cysts } \mathrm{g}^{-1} \mathrm{dw}\end{array}$ & $\begin{array}{l}\text { Total density } \\
\text { cysts g }{ }^{-1} \text { dw }\end{array}$ & $S$ & $d$ & $H^{\prime}$ & $J^{\prime}$ \\
\hline Station 40 & $389 \pm 127$ & 1167 & $18 \pm 2.7$ & $2.9 \pm 0.3$ & $2.2 \pm 0.1$ & $0.7 \pm 0.1$ \\
\hline Station 45 & $329 \pm 123$ & 987 & $11 \pm 4.4$ & $1.8 \pm 0.9$ & $0.5 \pm 0.2$ & $0.5 \pm 0.2$ \\
\hline
\end{tabular}

Abundance: average \pm standard deviation from three replicates. Total density: sum of cyst abundances observed in three replicates from each station. $S$ : number of taxa identified (average \pm standard deviation). $d$ : Margalef diversity index. $H^{\prime}$ : Shannon diversity index. $J^{\prime}$ : Pielou's evenness index. 
TABLE 4: Results of SIMPER analysis for resting stages from surface sediments at stations 40 and 45 in Bay of Vlorë.

\begin{tabular}{|c|c|c|c|c|c|}
\hline Taxa & Av. Abund & Av. Sim & $\mathrm{Sim} / \mathrm{SD}$ & Contrib\% & Cum.\% \\
\hline \multicolumn{6}{|c|}{ Station 40} \\
\hline \multicolumn{6}{|c|}{ Average similarity: 56.81} \\
\hline Scrippsiella trochoidea medium type & 119.92 & 21.61 & 7.45 & 38.05 & 38.05 \\
\hline Scrippsiella trochoidea small type & 67.73 & 15.81 & 6.14 & 27.83 & 65.87 \\
\hline Scrippsiella trochoidea rough type & 35.13 & 6.44 & 2.78 & 11.34 & 77.21 \\
\hline Pentapharsodinium tyrrhenicum type 1 & 27.33 & 5.18 & 8.96 & 9.13 & 86.34 \\
\hline Calciodinellum albatrosianum & 24.53 & 4.94 & 7.24 & 8.69 & 95.03 \\
\hline \multicolumn{6}{|c|}{ Station 45} \\
\hline \multicolumn{6}{|c|}{ Average similarity: 40.37} \\
\hline Scrippsiella trochoidea medium type & 174.21 & 40.03 & 5.87 & 99.16 & 99.16 \\
\hline
\end{tabular}

Stations 40 and 45

Average dissimilarity $=58.20$.

Cysts ascribed to the paleontological taxa Bicarinellum tricarinelloides and Calciperidinium asymmetricum both germinated, thus confirming that they belong to modern taxa. The active stages obtained were tentatively identified as scrippsielloid dinoflagellates.

An unknown ciliate cyst, with a papula at both extremities, produced an active stage identifiable as belonging to the Strombidium genus (Figure 2).

\section{Discussion}

The total number of resting stage morphotypes recognized in the present study is particularly high compared with other studies in the Mediterranean. None of these studies gave a number higher than the one reported here, despite being based on a larger geographical area (the whole North Adriatic, in [24]) or a higher number of samples (157 sediment samples in [5]). This richness could be due to our enhanced ability, with the passage of time, to identify cysts from different species, but it could also depend on the consideration of different depths in the sediments. Indeed, the other mentioned studies only reported cysts from the sediment surface, while in the present case the type list grew by more than $60 \%$ when below-surface layers were considered.

As a consequence of its richness, the reported list adds 42 morphotypes to the Albanian list and 13 alternative morphotypes to already known taxa. This fact clearly demonstrates that the description of cyst assemblages in coastal Mediterranean areas is still far from being exhaustive.

The discovery of differences in the benthic species assemblage with respect to the plankton is partially due to the use in cyst studies of a terminology derived from paleontological studies which has yet to be standardised with reference to modern terminology. However, it is evident that the active stages in the water column assemblage of the Bay of Vlore [15] differ in number and quality from that of the bottom sediments reported in the present study. By way of example, and only considering the surface sediment layer (i.e., the most affected by recent sinking and/or re-suspension), 4 different species of Scrippsiella (Dinophyta) were isolated as cysts, but only 2 were reported [15] as active stages in the water column for the whole bay. Moreover, in this study 5 different cyst types for the single species $S$. trochoidea were identified, differing in terms of size and wall. This is evidence of great intraspecific diversity, but it could be also a sign of the presence of cryptic species, as discussed by Montresor et al. [25], differing in cyst morphology but not in that of the swimming stage.

The rotifer Synchaeta sp. was not found in the water column, but its resting eggs were easily recognizable and abundant, in the sediments.

While the case of $S$. trochoidea confirms that much remains to be discovered about the morphological variability of cysts produced by the same species (see [26], for Dinophyta or [27], for Calanoida), Synchaeta sp. is a clear case of a species not detected in the active plankton assemblage but waiting in the sediments for a favourable moment to rejoin the water column.

Also worthy of attention is the observation of a Ciliophora cyst with two papulae on opposite sides (Figure 2), which has never been reported before.

A study of plankton composition was carried out in the same site during the same scientific cruise (January 2008) as the present study [15]. In January 2008, the phytoplankton and the microzooplankton included a total of 178 categories. Considering only the main cyst producers (dinoflagellates and ciliates), examination of the water column at 16 stations gave a total of 76 taxa (48 dinoflagellates, 28 ciliates). The present analysis of sediments, from just 2 stations, gave a total of 75 taxa. This striking similarity of values was not, however, reflected in the taxonomic composition of the 2 compartments. Indeed, 36 cyst types were identified as taxa not present in the plankton list for the same period (January 2008). This number would be even higher if we considered only plankton from stations close to the two used here for the sediments.

It was not possible to correlate cyst abundance along the sediment column with age of deposition, which would require dating of the sediment layers. In any case, our results showed that the total abundance of cysts in the upper layers 


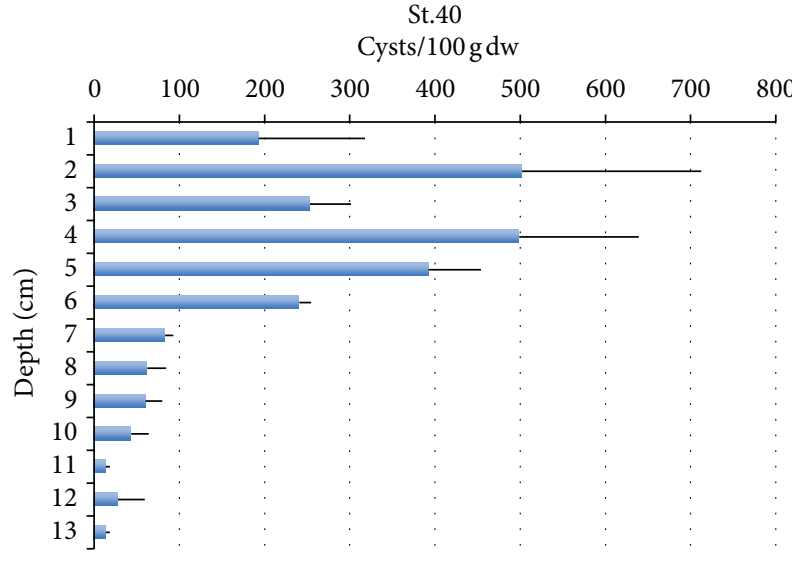

(a)

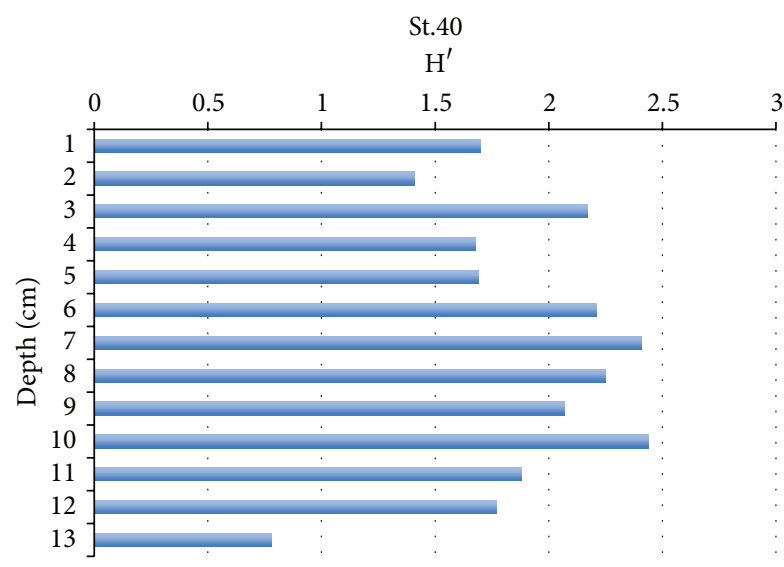

(c)

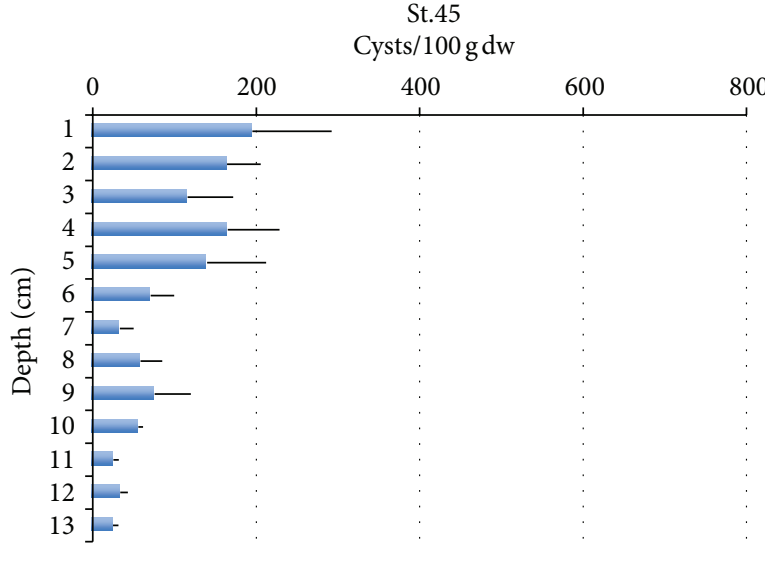

(b)

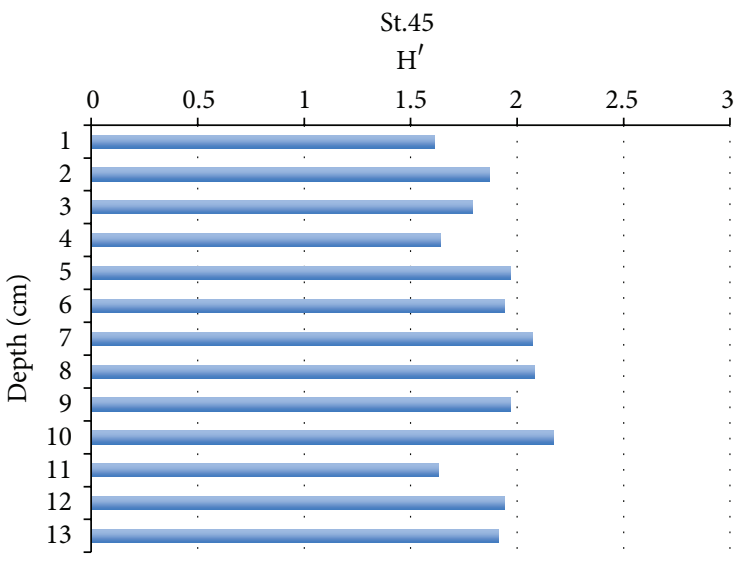

(d)

FIGURE 4: Resting stage abundance (average \pm standard deviations) and Shannon's index $\left(H^{\prime}\right)$ values recorded for each $\mathrm{cm}$ layer of sediment cores collected at two investigated stations in Bay of Vlorë (Albania).

was up to 10 times greater than in lower ones. The sharp decrease in abundance below the 5 th $\mathrm{cm}$ of depth, at least at station 40, does, however, suggest that an event occurred at a certain moment in the history of the plankton in the Bay of Vlorë, a suggestion that clearly requires further study. Indeed, due to its position, station 40 is a candidate for studies of the history of cyst production (and their arrival in the sediment). Located in a depression on the seabed, the depth of St. 40 $(-54 \mathrm{~m})$ probably favours the sedimentation of fine particles and the depletion of oxygen content, and the deposition and accumulation of sinking resting stages can thus be considered undisturbed. In addition, the observed fall in diversity from lower to upper layers could be correlated with the growth of cultural eutrophication (i.e., urban development), as proposed for Tokyo Bay and Daja Bay [28].

This situation at St. 45 (depth $28 \mathrm{~m}$ ) is not completely identical. It is near the slope of a detritus cone where materials from river Vjosa accumulate and marine currents possibly act at a different rate from those acting on St. 40.

Incubation of encysted forms under controlled conditions to obtain germination is a useful tool for confirming the identification made by observation of the cyst. In some cases, different species produce very similar cysts, especially when the morphology is very simple, that is, spherical, without processes or wall structures. In the present study, we observed many Dinophyta cysts with the same basic morphology, that is, round body and smooth brown wall with no apparent signs of paratabulation or spines or processes. Their germination allowed us to classify this basic type into at least 6 species. Round brown cysts are typical of Protoperidinium species $[29,30]$, but we also recognized Diplopsalis lenticula, Gymnodinium nolleri, and Oblea rotunda, as well as 3 additional Protoperidinium species. In the same way, it was possible to distinguish between Alexandrium minutum and Scrippsiella sp.1, whose cysts are very similar and whose distinctive features are recognizable only after germination.

Conversely, analysis of cysts may allow us to identify species whose active stages are indistinguishable, at least by optical microscope. This is the case in the present study for the Scrippsiella group, which produces active cells that are very difficult to distinguish, although their cysts differ in terms of the type of calcareous covering, colour, and the presence of spines [31, 32]. 


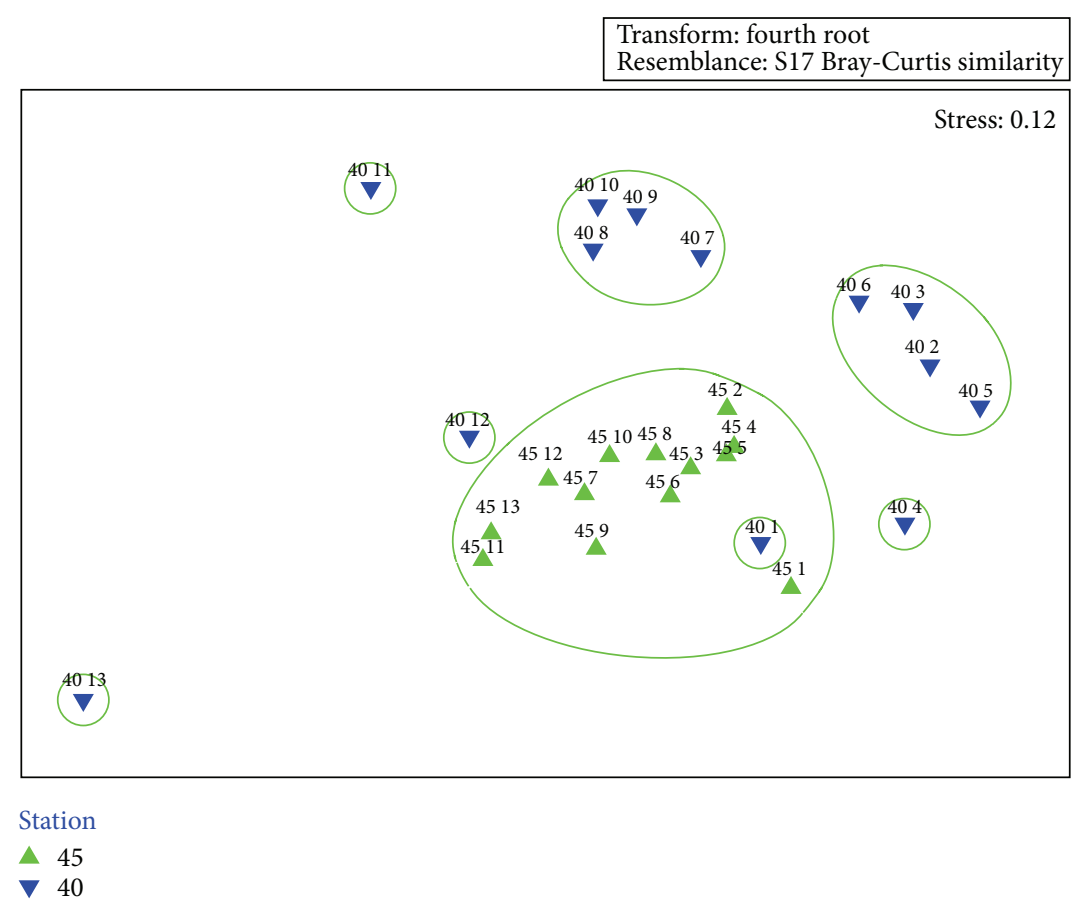

FIGURE 5: nMDS plot of samples from each cm of sediment cores collected at stations 40 and 45 in Bay of Vlorë. Hierarchical clustering superimposed with cutoff at $70 \%$ similarity.

TABLE 5: Results of SIMPER analysis for resting stages in sediment cores collected at stations 40 and 45 in Bay of Vlorë.

\begin{tabular}{|c|c|c|c|c|c|}
\hline Taxa & Av. Abund & Av. Sim & $\mathrm{Sim} / \mathrm{SD}$ & Contrib\% & Cum.\% \\
\hline \multicolumn{6}{|c|}{ Station 40} \\
\hline \multicolumn{6}{|c|}{ Average similarity: 44.16} \\
\hline Centropages sp. & 1.77 & 8.77 & 0.86 & 19.86 & 19.86 \\
\hline Codonellopsis schabii & 2.10 & 7.00 & 1.31 & 15.86 & 35.72 \\
\hline Acartia clausi/margalefi & 1.56 & 6.21 & 1.22 & 14.06 & 49.78 \\
\hline Synchaeta sp. spiny type & 1.47 & 5.31 & 1.10 & 12.02 & 61.81 \\
\hline Penilia avirostris & 1.14 & 4.47 & 0.98 & 10.13 & 71.93 \\
\hline Brachionus plicatilis & 0.96 & 2.90 & 0.81 & 6.56 & 78.49 \\
\hline Stenosemella ventricosa & 0.78 & 1.47 & 0.55 & 3.32 & 81.81 \\
\hline Strobilidium sp. & 0.73 & 1.43 & 0.51 & 3.23 & 85.04 \\
\hline Scrippsiella spp. & 0.57 & 0.95 & 0.36 & 2.14 & 87.18 \\
\hline Gonyaulax spp. & 0.54 & 0.71 & 0.34 & 1.60 & 88.79 \\
\hline Strombidium conicum & 0.44 & 0.69 & 0.33 & 1.57 & 90.36 \\
\hline \multicolumn{6}{|c|}{ Station 45} \\
\hline \multicolumn{6}{|c|}{ Average similarity: 52.61} \\
\hline Acartia clausi/margalefi & 1.88 & 12.13 & 2.08 & 23.05 & 23.05 \\
\hline Synchaeta sp. spiny type & 1.73 & 10.91 & 1.59 & 20.74 & 43.79 \\
\hline Codonellopsis schabii & 1.43 & 6.73 & 1.12 & 12.80 & 56.59 \\
\hline Strobilidium sp. & 1.12 & 6.05 & 0.92 & 11.51 & 68.10 \\
\hline Centropages sp. & 1.20 & 6.05 & 1.02 & 11.50 & 79.60 \\
\hline Brachionus plicatilis & 0.84 & 2.73 & 0.63 & 5.19 & 84.79 \\
\hline Acartia sp.1 & 0.75 & 2.57 & 0.58 & 4.89 & 89.67 \\
\hline Lingulodinium polyedrum & 0.74 & 2.39 & 0.59 & 4.54 & 94.22 \\
\hline
\end{tabular}

Groups 40 and 45.

Average dissimilarity $=58.63$. 
Worthy of special attention here is the recovery during the present study of Dinophyta cysts whose active stages have yet to be identified. As cysts, they are still classified with a paleontological name in accordance with their description from Pleistocene to Pliocene sediment strata in the Mediterranean [33]. Two of these cyst types (Bicarinellum tricarinelloides and Calciperidinium asymmetricum) were successfully germinated, producing motile forms recognisable as belonging to the Calciodinellaceae family. In any case their frequent observation in surface sediments in other Mediterranean areas [23,34] and in sediment traps [35] is a clear sign that these species are present in the water column today and need to be better identified.

\section{Conflict of Interests}

The authors declare that there is no financial interest or conflict of interests involved.

\section{Acknowledgments}

The present study was funded by CoNISMa in the framework of the INTERREG III Italy, Albania Programme, CISM Project (Technical Assistance for Establishing and Management of an International Center for Marine Studies in Albania). The authors thank the crew of the Research Vessel Universitatis (CoNISMa) for the valuable field assistance, Professor Sami Souissi (Université de Lille, France) who took care of the paper editing, and two anonymous referees who were extremely helpful in the improvement of the paper.

\section{References}

[1] G. Belmonte, P. Castello, M. R. Piccinni et al., "Resting stages in marine sediments off the Italian coast," in Biology and Ecology of Shallow Coastal Waters, A. Elefteriou, C. J. Smith, and A. D. Ansell, Eds., pp. 53-58, Olsen \& Olsen, Fredensborg, Denmark, 1995.

[2] N. H. Marcus and F. Boero, "Minireview: the importance of benthic-pelagic coupling and the forgotten role of life cycles in coastal aquatic systems," Limnology and Oceanography, vol. 43, no. 5, pp. 763-768, 1998.

[3] A. Giangrande, S. Geraci, and G. Belmonte, "Life-cycle and lifehistory diversity in marine invertebrates and the implications in community dynamics," Oceanography and Marine Biology, vol. 32, pp. 305-333, 1994.

[4] F. Boero, G. Belmonte, G. Fanelli, S. Piraino, and F. Rubino, "The continuity of living matter and the discontinuities of its constituents: do plankton and benthos really exist?" Trends in Ecology and Evolution, vol. 11, no. 4, pp. 177-180, 1996.

[5] S. Moscatello, F. Rubino, O. D. Saracino, G. Fanelli, G. Belmonte, and F. Boero, "Plankton biodiversity around the Salento Peninsula (South East Italy): an integrated water/sediment approach," Scientia Marina, vol. 68, no. 1, pp. 85-102, 2004.

[6] F. Rubino, O. D. Saracino, S. Moscatello, and G. Belmonte, "An integrated water/sediment approach to study plankton (a case study in the southern Adriatic Sea)," Journal of Marine Systems, vol. 78, no. 4, pp. 536-546, 2009.
[7] F. Rubino, O. D. Saracino, G. Fanelli, G. Belmonte, A. Miglietta, and F. Boero, "Life cycles and pelago-benthos interactions," Biologia Marina Mediterranea, vol. 5, pp. 253-259, 1998.

[8] G. Belmonte, A. Miglietta, F. Rubino, and F. Boero, "Morphological convergence of resting stages of planktonic organisms: a review," Hydrobiologia, vol. 355, no. 1-3, pp. 159-165, 1997.

[9] N. H. Marcus, R. Lutz, W. Burnett, and P. Cable, "Age, viability, and vertical distribution of zooplankton resting eggs from an anoxic basin: evidence of an egg bank," Limnology and Oceanography, vol. 39, no. 1, pp. 154-158, 1994.

[10] X. Jiang, G. Wang, and S. Li, "Age, distribution and abundance of viable resting eggs of Acartia pacifica (Copepoda: Calanoida) in Xiamen Bay, China," Journal of Experimental Marine Biology and Ecology, vol. 312, no. 1, pp. 89-100, 2004.

[11] H. U. Dahms, X. Li, G. Zhang, and P. Y. Qian, "Resting stages of Tortanus forcipatus (Crustacea, Calanoida) in sediments of Victoria Harbor, Hong Kong," Estuarine, Coastal and Shelf Science, vol. 67, no. 4, pp. 562-568, 2006.

[12] G. Belmonte, P. Pirandola, S. Degetto, and F. Boero, "Abbondanza, vitalità e distribuzione verticale di forme di resistenza nei sedimenti del Nord Adriatico," Biologia Marina Mediterranea, vol. 6, pp. 172-178, 1999.

[13] S. Ribeiro, T. Berge, N. Lundholm, T. J. Andersen, F. Abrantes, and M. Ellegaard, "Phytoplankton growth after a century of dormancy illuminates past resilience to catastrophic darkness," Nature Communications, vol. 2, no. 1, article 311, 2011.

[14] N. G. Hairston Jr., R. A. Van Brunt, C. M. Kearns, and D. R. Engstrom, "Age and survivorship of diapausing eggs in a sediment egg bank," Ecology, vol. 76, no. 6, pp. 1706-1711, 1995.

[15] S. Moscatello, C. Caroppo, E. Hajdëri, and G. Belmonte, "Space distribution of phyto- and microzooplankton in the Vlora Bay (Southern Albania, Mediterranean Sea)," Journal of Coastal Research, no. 58, pp. 80-94, 2011.

[16] P. Maiorano, F. Mastrototaro, S. Beqiraj et al., "Bioecological study of the benthic communities on the soft bottom of the Vlora Gulf (Albania)," Journal of Coastal Research, no. 58, pp. 95-105, 2011.

[17] C. J. Bolch and G. M. Hallegraeff, "Dinoflagellate cysts in recent marine sediments from Tasmania, Australia," Botanica Marina, vol. 33, pp. 173-192, 1990.

[18] J. A. Sonneman and D. R. A. Hill, "A taxonomic survey of cystproducing dinoflagellates from recent sediments of Victorian coastal waters, Australia," Botanica Marina, vol. 40, no. 3, pp. 149-177, 1997.

[19] A. Rochon, A. De Vernal, J. L. Turon, J. Matthiessen, and M. J. Head, "Distribution of recent dinoflagellate cysts in surface sediments from the North Atlantic Ocean and adjacent seas in relation to sea-surface parameters," AASP Contribution Series, vol. 35, pp. 1-152, 1999.

[20] P. C. Reid and A. W. G. John, "Tintinnid cysts," Journal of the Marine Biological Association of the United Kingdom, vol. 58, pp. 551-557, 1978.

[21] P. C. Reid and A. W. G. John, "Resting cysts in the ciliate class Polymenophorea: phylogenetic implications," Journal of Protozoology, vol. 30, pp. 710-712, 1978.

[22] T. Onbè, "Sugar flotation method for sorting the resting eggs of marine cladocerans and copepods fron sea bottom sediments," Bulletin of the Japanese Society for the Science of Fish, vol. 44, p. 1411, 1978.

[23] F. Rubino, M. Belmonte, C. Caroppo, and M. Giacobbe, "Dinoflagellate cysts from surface sediments of Syracuse Bay 
(Western Ionian Sea, Mediterranean)," Deep-Sea Research Part II, vol. 57, no. 3-4, pp. 243-247, 2010.

[24] F. Rubino, G. Belmonte, A. M. Miglietta, S. Geraci, and F. Boero, "Resting stages of plankton in recent North Adriatic sediments," Marine Ecology, vol. 21, no. 3-4, pp. 263-284, 2000.

[25] M. Montresor, S. Sgrosso, G. Procaccini, and W. H. C. F. Kooistra, "Intraspecific diversity in Scrippsiella trochoidea (Dinophyceae): evidence for cryptic species," Phycologia, vol. 42, no. 1, pp. 56-70, 2003.

[26] A. Rochon, J. Lewis, M. Ellegaard, and I. C. Harding, "The Gonyaulax spinifera (Dinophyceae) "complex": perpetuating the paradox?" Review of Palaeobotany and Palynology, vol. 155, no. 1-2, pp. 52-60, 2009.

[27] G. Belmonte, "Diapause egg production in Acartia (Paracartia) latisetosa (Crustacea, Copepoda, Calanoida)," Bolletino di Zoologia, vol. 59, pp. 363-366, 1992.

[28] Z. Wang, K. Matsuoka, Y. Qi, J. Chen, and S. Lu, "Dinoflagellate cyst records in recent sediments from Daya Bay, South China Sea," Phycological Research, vol. 52, no. 4, pp. 396-407, 2004.

[29] R. Harland, "A review of recent and quaternary organic-walled dinoflagellate cysts of the genus Protoperidinium," Paleontology, vol. 25, pp. 369-397, 1982.

[30] J. Lewis, J. D. Dodge, and P. Tett, "Cyst-theca relationship in some Protoperidinium species (Peridiniales) from Scottish sea lochs," Journal of Micropalaeontology, vol. 3, pp. 25-34, 1984.

[31] M. Gottschling, R. Knop, J. Plötner, M. Kirsch, H. Willems, and H. Keupp, "A molecular phylogeny of Scrippsiella sensu lato (Calciodinellaceae, Dinophyta) with interpretations on morphology and distribution," European Journal of Phycology, vol. 40, no. 2, pp. 207-220, 2005.

[32] H. Gu, J. Sun, W. H. C. F. Kooistra, and R. Zeng, "Phylogenetic position and morphology of thecae and cysts of Scrippsiella (Dinophyceae) species in the East China Sea," Journal of Phycology, vol. 44, no. 2, pp. 478-494, 2008.

[33] G. J. M. Versteegh, "New Pliocene and Pleistocene calcareous dinoflagellate cysts from southern Italy and Crete," Review of Palaeobotany and Palynology, vol. 78, no. 3-4, pp. 353-380, 1993.

[34] K. J. S. Meier and H. Willems, "Calcareous dinoflagellate cysts in surface sediments from the Mediterranean Sea: distribution patterns and influence of main environmental gradients," Marine Micropaleontology, vol. 48, no. 3-4, pp. 321-354, 2003.

[35] F. Rubino, S. Moncheva, M. Belmonte, N. Slabakova, and L. Kamburska, "Resting stages produced by plankton in the Black Sea-biodiversity and ecological perspective," Rapport Commission International pour l'Exploration Scientifique de la Mer Mediterranee, vol. 39, p. 399, 2010. 

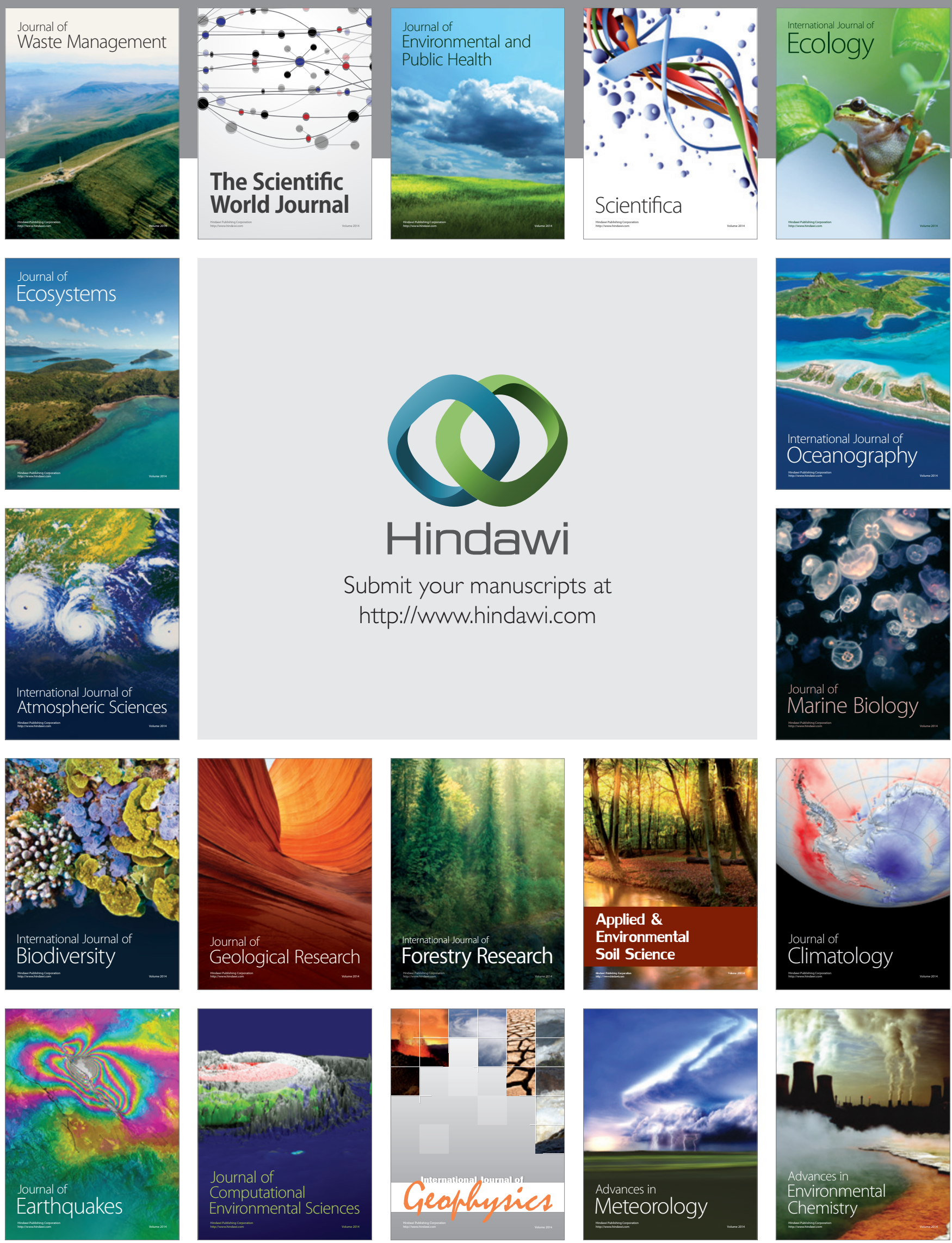